\title{
Description of Gnus fulvipes n. sp. from Japan (Diptera, Simuliidae) ${ }^{1)}$
}

\author{
Hiroshi ONO* \\ Nukabira Biological Institute Obihiro University, Nukabira, \\ Kamishihoro, Hokkaido 080-15, Japan
}

(Received: June 15, 1978)

\begin{abstract}
Gnus fulvipes n. sp. is described based on the specimens taken from the several streams in the Oshima Peninsula, Southern Hokkaido. This new species seems to be assinged to the malyshevi group of the genus Gnus and is closely related to Gnus daisense (TAKAHASHI, 1950). However, the broad ventral plate of the male and arrangement of pupal gill filaments easily separate this species from the other included species of this group.
\end{abstract}

In June, 1977, many larvae and pupae of a Gnus species were collected from considerably fast steady current of the several streams in the Oshima Peninsula, Southern Hokkaido. The reared adults, associated with pupal skins and larvae are allied to those of Gnus daisense (TAKAHASHI, 1950) from Eastern Hokkaido (Tokachi Prefecture), Honsyu (San-in District) and Shikoku. However, the present specimens can be distinguished from the latter and other known species of the genus by the several taxonomic characters pointed out later. They are considerded to represent a new species as described in this paper.

\section{DESCRIPTION}

Gnus fulvipes ONo n. sp. (Figs. 1-27)

[Japanese name: Oshima-yama-buyu]

Female. Length : body, 3.3-3.4 mm; wing, 3.0-3.3 mm. General body colour dull black; legs yellowish orange.

Head dull black, slightly narrower than thorax; posterior and undersurface sparsely covered with black hairs. Frons shiny black, broad, diverging above and narrowed to-

1) Contribution No. 80 from the Laboratory of Entomology, Obihiro University

* 小野 決：带広畜産大学生物研究所（兵 080-15 北海道河東郡上士幌町棣平) wards antennal base; $\mathrm{a}: \mathrm{b}: \mathrm{c}=13: 11: 12(\mathrm{a}$ : greatest width of frons, $\mathrm{b}:$ narrowest width of frons and $c$ : height of frons, $c f$. Fig. 9). Clypeus greyish pollinose, longer than its greatest width, with scattered brown hairs. Antenna (Fig. 2) composed of $2+9$ segments and longer than that of male; scape and pedicel pale yellow with long, coarser brown hairs distally; flagellar segments dark brown, covered with greyish white pubescence; first flagellomere considerably longer than other segments and tinged with yellow on basal $1 / 3$; last flagellomere slender, with 2 long apical hairs. Maxillary palp (Fig. 4) grey, covered with black hairs; proportional length of each segment from base to apex $1: 1: 2: 2: 4-4.5 ; 3$ rd segment swollen, about 2 times as long as greatest width; sensory vesicle (Fig. 5) oblong, about $1 / 4$ as long as 3 rd segment and proximally situated. Blade of maxilla (Fig. 6) with 25-28 (14 inner teeth and 11-14 outer ones) retrorse teeth. Mandible (Fig. 7) with 39 (11 outer teeth and 28 weak inner ones) fine serrations. Median distal margin of cibarium (Fig. 8) armed with many minute granules; dorsolateral arm broad and sclerotized along outer margin.

Thorax dull black. Pronotum and scutum dull black, covered with short, fine recumbent and pale grey hairs; prescutellum half 
shiny. Scutellum dull black, with short pale yellow hairs and long erect black hairs. Postscutellum black, bare. Pleuron, pleural membrane and katepisternum dark brown, bare. Wing hyaline; veins grey; costa with fine, brown hairs and spinules; ventral surface of subcosta with a single row of hairs; basal section of radius bare dorsally; basal cell present vestigially. Halter pale yellows. All legs with similar colouration. Coxa, trochanter, femur and tibia yellowish orange, with short pale yellow hairs; distal end of femur black with long brown hairs; distal part of tibia with brown hairs, distal $1 / 4$ of fore tibia and distal $1 / 3$ of hind tibia black; basitarsus orange with long black hairs and distal $1 / 3$ of the segment tinged with black; remaining tarsal segment entirely black, with black short hairs, but basal $1 / 2$ of hind 2nd tarsal segment yellowish orange; fore basitarsus dilated, about 3 times as long as its greatest width; hind basitarsus almost parallel-sided with fine, long black tarsal brushes. Calcipala and pedisulcus well developed. Claw slender with a short subbasal tooth.

Abdomen black, sparsely covered with black hairs; sternite II pale yellow, rounded, densely covered with pale yellow pollinosity; terga VII and VIII half shiny black, with coarse, long and erect black hairs. Basal fringe long, pale yellow. Genitalia as shown in Fig. $14(\mathrm{a}, \mathrm{b})$. Ovipositor lobe narrow, not curled apically, bare and brown with 8 microsetae and numerous granules along proximal margin; inner and posterior margins slightly concave. Stem of genital fork slender, long and heavily sclerotized; arm relatively short, wide and having one blunt process distally; the process heavily sclerotized; basal half of arm broad, its turning point making a right angle with stem. Anal lobe broad, mitre-shaped in lateral view, and elliptical in ventral view, with microsetae on inner and ventral portions and with macrosetae on outer and apical parts. Cercus semicircular in lateral view. Spermatheca large in size, subelliptical, heavily pigmented without internal hairs.

Male. Length : body, 3.1-3.6 mm; wing, 2.8-3.3 mm. General body colour black, darker than that of female; legs greyish yellow.

Head wider than thorax. Frons with erect black pile. Clypeus with grey pollinosity and long brown hairs. Antenna (Fig. 1) shorter than that of female; first flagellomere longest of all segments. Maxillary palp (Fig. 3) more slender and shorter than that of female, with 5 segments in proportion of $2: 2: 5: 7: 14-15$; sensory vesicle spherical, about $1 / 6$ times as long as segment III.

Scutum velvety black, covered with short, recumbent pale yellow hairs; front part of scutum not shown silver-polished pattern. Scutellum dark brown with long, coarse, erect brown hairs. Postscutellum and pleuron dull black with grey pollinosity. Pleural membrane and katepisternum brown, bare. Wing nearly as female, except for distal half of subcosta bare. Coxa and trochanter brown with short pale yellow hairs. Femur and tibia greyish yellow, with distal half becoming darker towards distal end, and with short pale yellow hairs. Tarsi black with short black hairs; hind basitarsus greyish brown and almost parallel-sided; fore and mid basitursus slender, and fore one about 4.5 times as long as width.

Abdomen velvety black, sparsely covered with erect, black hairs. Basal scale black. Genitalia as shown in Fig. 15 (a, b, c, d and e). Basimere cylindrical quadrate, as long as its greatest width, outer and distal half moderately setose. Distimere slender, cylindrical, tapering distally, nearly as long as basimere and about $1 / 2$ as wide as length, with a terminal spine, moderately setose. Vental plate transverse, wider than length, rounded apically and spade-shaped; the apical margin slightly projected and posteromedially with a laterally compressed, beaklike haired process directed ventrally; basal arm slender, inclined obliquely at the apex. Median sclerite broad, flat, rather slender apically. Endoparameral organ with multiple, long and heavily sclerotized; hooks intermingled with some short hooks; total number of these parameral hooks about 20 ; parameral plate brown, with 2 long spines.

Pupa. Length 3.4-3.4 mm (pupal body). Respiratory organ $1.1-1.3 \mathrm{~mm}$, consisting of a short and broad base with many spicules 
and 16 filaments; base giving rise to 3 short primary trunks with ventral one broadest; ventral trunk giving rise to 4 broad and thick filaments; lateral trunk giving rise to 4 filaments, each branched into 2 slender filaments, with total number of filaments 8 ; dorsal trunk giving rise to 2 filaments, each branched into 2 slender filaments, with total number of filaments 4 . All filaments brownish yellow, slightly tapering distally, with numerous transverse furrows; all tubercles on filamental surface almost equal size. Head and thorax yellowish brown covered with numerous, minute, rounded dark brown tubercles. Head trichomes 3 pairs, all dark brown, long and simple; two anteriorly and one posteriorly. Thoracic trichomes 8 pairs; 2 laterally, 4 dorsally, and ventrally; all dark brown and simple except 2 dorsal pairs bifid. Abdominal segments consisted of extremely thin skins which are transparent, except terga I, II and IX. Tergum I grey, with 3 short setae on either side. Tergum II pale grey, with 2 short, fine and anteriorly-directed spines and 5 long scattered setae on either side. Terga III and IV each with 4 fine anteriorly directed hooked spines near posterior margin and 1 short seta on either side. Tergum V bare. Terga VI and VII each with 1 anteriorly directed hooked spine on either side. Tergum VIII with a transverse row of 5 posteriorly directed spines along the anterior margin on either side. Tergum IX pale grey and strongly sclerotized. Caudal spine situated upon rather prominent convexity, dark grey, extremely short, with dull tip directed posteriorly; bases of caudal spines broadly separated. Sternum III with 3 long setae on either side. Sternum IV with a hook and a long seta on either side. Sternum V with a bifid hook and a short seta on either side. Sternum VI with a pair of bifid hooks on either side and with a pair hooked spines near posterior margin which are strongly curved and the tips directed anteriorly. Sternum VII with a bifid hook and a short hook on either side. All hooks of sterna directed anteriorly. Cocoon (Fig. 17), length 3.8-4.2 mm, width $2.0-2.2 \mathrm{~mm}$, shoe-shaped, more tigthly woven than that of $G$. daisense; its frontal margin with basket-work extension as shown in Fig. 17.

Mature larva. $6.3-7.0 \mathrm{~mm}$ long. Body pale grey. Head capsule greyish yellow; cephalic apotome (Fig. 22) covered with dark speckles posteriorly and greyish yellow anteriorly; head spots usually indistinct, surrounding area of posteromedial and posterolateral spots darkened; eye spots rather small, surrounded by narrow, clear area usually differentiated from rest of general plate; eyebrow usually distinct. Antenna (Fig. 27) longer than stalk of cephalic fan; proportional length of each segment I-IV about $17: 14: 10: 1$; segments I and II transparent, segment III pale yellow; segment II with weak secondary annulation. Cephalic fan with 34-36 rays. Hypostomial teeth as shown in Fig. 20, median and corner teeth prominent. Postgenal cleft deep, tapering anteriorly, almost reaching to hind margin of hypostomium. Inner subapical ridge of mandible (Fig. 23) with 3 lightly pigmented

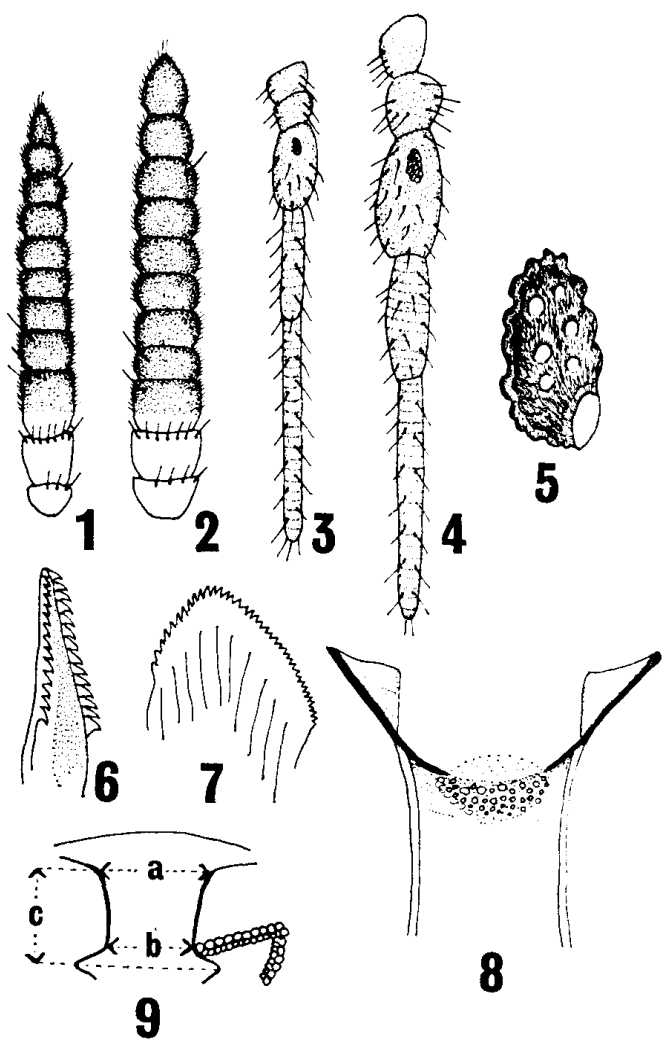

Figs. 1-9 Gnus fulvipes n. sp. (adults)

1 , antenna of male; 2, antenna of female; 3 , maxillary palp of male; 4 , maxillary palp of female; 5 , sensory vesicle of female; 6, maxilla of female; 7, mandible of female; 8 , distal part of cibarium of female; 9 , frons of female 


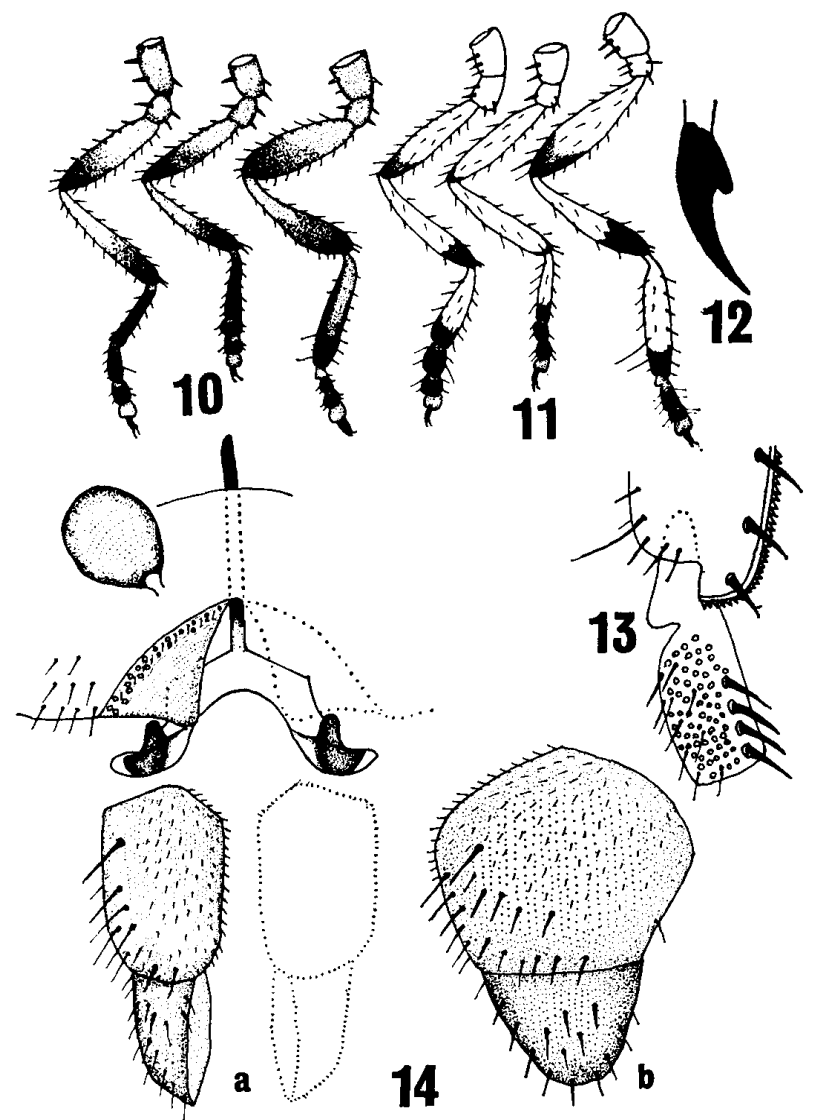

Figs. 10-14 Gnus fulvipes n. sp. (adults) 10, fore, mid and hind legs of male; 11, legs of female; 12 , claw ; 13 , calcipala and pedisulcus of female; 14a, genitalia of female, ventral view; $14 \mathrm{~b}$, anal lobe and cercus, lateral view

comb-teeth; inner margin with 8 almost transparent, long slender teeth; inner area with 8 or more short, thick teeth; posterior margin of mandible with one large tooth and one small tooth. Maxillary palp 3.0 times as long as width at base. Lateral plate of proleg (Fig. 26) wide, slightly sclerotized, extending to $1 / 2$ length of apical segment. Each abdominal segment with dark greyish band. Rectal gills branching as shown in Fig. 25 ; each lobe with 3 short, finger-like secondary lobules. Anal sclerite (Fig. 24) with posteroventral arms longer than anterodorsal arms. Posterior circlet consisted of 112 rows of 14-16 hooks. Vental papilae absent.

Type series. Holotype: Female with associated pupal skin, preserved in alcohol solution. Reared from pupa taken in a stream of the left tributary of the Assabu River, Hiyama-gun, Hokkaido, June 25, 1977

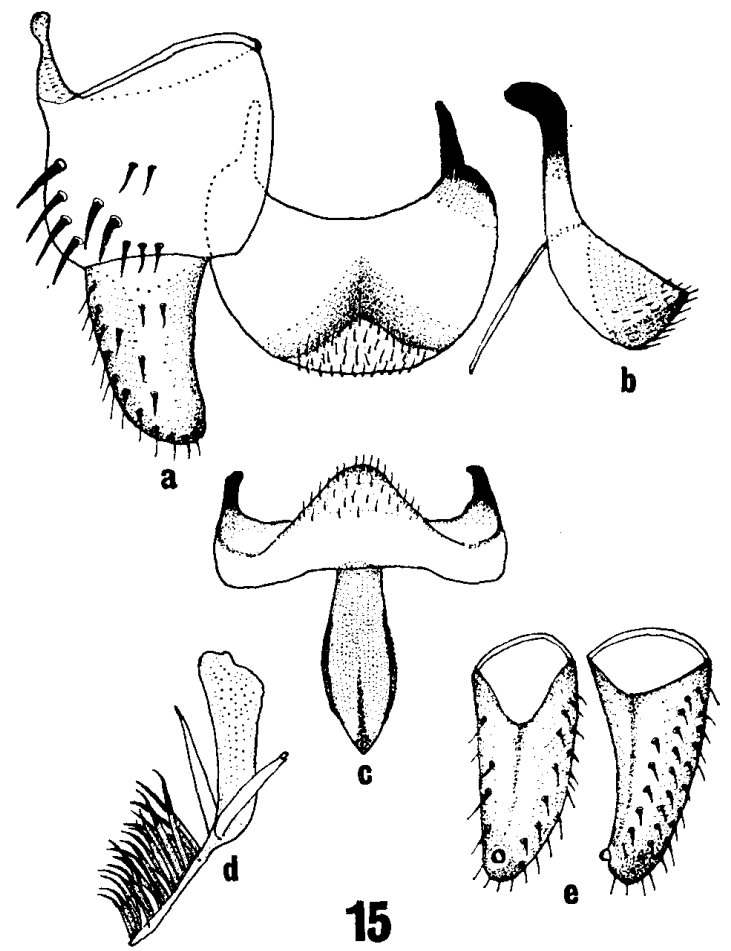

Fig. 15 Gnus fulvipes n. sp. (male genitalia) $a$, genitalia, ventral view; $b$, ventral plate, lateral view; c, ventral plate, end view and median sclerite; d, parameral organ; e, distimere, two view

(H. Ono leg.).

Allotype: Male, the same locality and data as the holotype.

Paratypes: Ten pairs of adults, 20 pupae and 20 larvae, preserved in alcohol solution. The locality and data are the same as the holotype.

Holotype and allotype will be deposited in the National Science Museum in Tokyo. Paratype are preserved in the Laboratory of Entomology, Obihiro University in Hokkaido.

Other localities. Kumaishi, Nishi-gun, Hokkaido: Small stream under the Kumoishi Pass, June 25, 1977. Futamata, Oshyamanbe, Yamakoshi-gun, Hokkaido: Small stream near the Futamata hot spring, June 26, 1977. All materials were collected by H. Ono.

Remarks. The shape of male ventral plate of $G$. fulvipes n. sp. which is broad, rounded and lacking serration, is closely similar to those of the striatum group of the genus Simulium. However, this new species seems to be assignable to the malyshevi group (DoROgOSTAJASKII et RUBTSOv, 1962) 


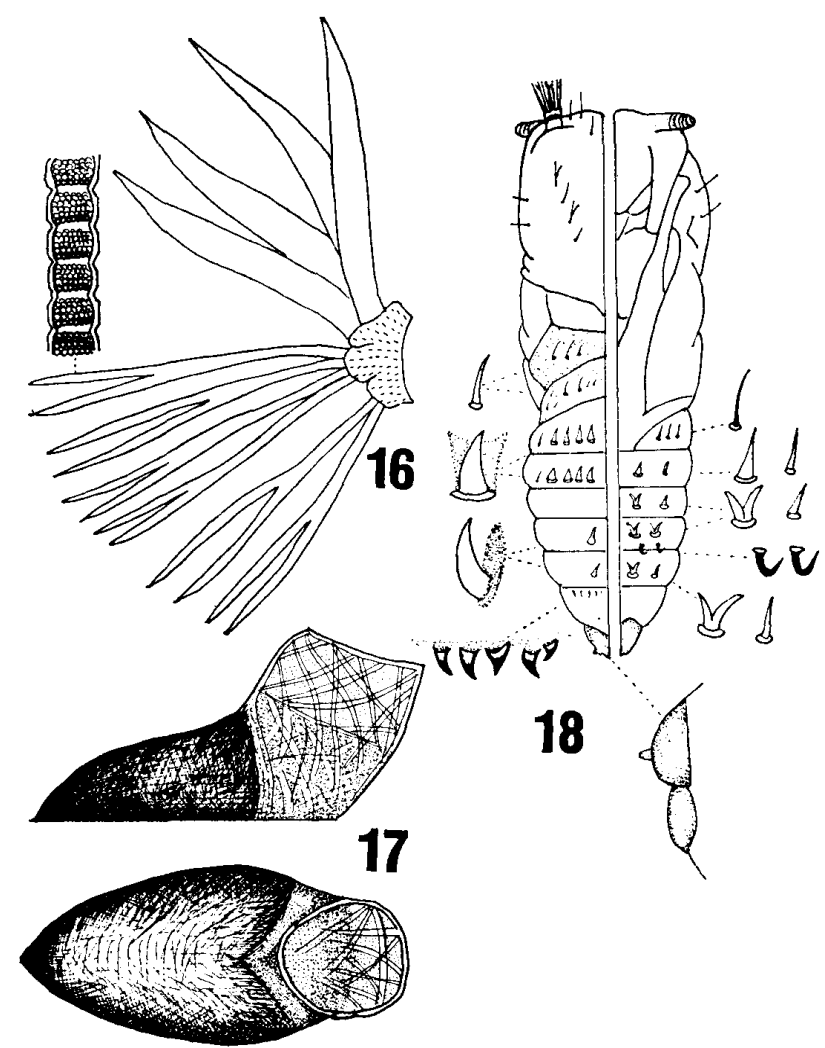

Figs. 16-18 Gnus fulvipes n. sp. (pupa and cocoon)

16 , respiratory organ; 17 , cocoon, lateral and dorsal view ; 18, pupal skin, left, dorsal and right half, ventral view (distal parts of filaments excepted)

of the genus Grus by the shape of the female terminalia, 16 respiratory filaments of the pupa, boot-shaped cocoon and larval deep postgenal cleft. The female and larva of this new species almost resemble those of the 4 known species included in this group (malysheri DOROGOSTAJASKII, ROBTSOV et VLASENKO, 1935, lucidum RUBTSOV, 1956 from USSR, albipes RUBTSOV, 1956 from USSR and Japan, and daisense TAKAHASHI, 1950 from Japan), while the arrangement of pupal respiratory filaments and the shape of male genitalia already mentioned above easily separate this new species from the other members of this group.

Biological notes. Full grown larvae and pupae were crowded on twig-like substances and dead leaves or debris. They were found in rapid, upland streams (Altitude about $300-500 \mathrm{~m}$ ) about 2 to $3 \mathrm{~m}$ in width and gravel bottomed. Biting habits are unknown.
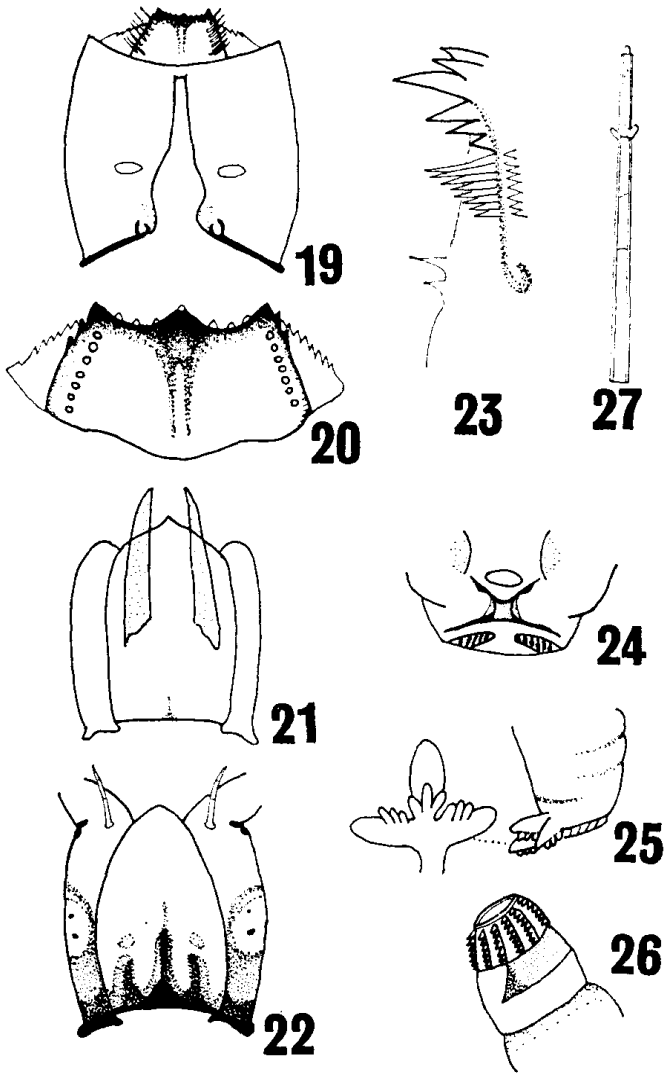

Figs. 19-27 Gnus fulvipes n. sp. (larvae) 19 , head capsule, dorsal view; 20 , hypostomium; 21, form of cephalic fans immediately after the moulting; 22, head capsule, ventral view; 23 , tip of mandible; 24 , larval rectal segments of abdomen, dorsal view; 25, rectal segments of abdomen, lateral view and rectal gill; 26 , proleg, lateral view; 27 , antenna

\section{ACKNOWLEDGEMENTS}

I should like to express my deep appreciation to Prof. Y. Nishijima, Director of the Laboratory of Entomology of Obihiro University, for his kind advice and reading through the manuscript. I am much gratefull to Dr. H. Takahasi for his kind guidance and offering valuable materials of Gnus daisense.

\section{REFERENCES}

Ogata, K. and M. Sasa (1954): Taxonomic notes on Simuliidae or black flies of Japan, with special references on the subgenera Eusimulium Roubaud and Nevermannia Enderlein (Diptera). Jap. J. Exp. Med., 24(5) : 325-333.

Ogata, K. and M. Sasa (1955) : Key to the adult females and pupae of Japanese Simuliidae and notes on the control of blackfly larvae by insecticides. Jap. J. Sanit. Zool., 6(1): 10-18 
(in Japanese).

Ogata, K., M. Sasa and T. Suzuki (1956): The Japanese Black Flies and Their Control. 162 pp., DDT Kyokai, Tokyo (in Japanese).

Okamoto, M. (1958): Studies on the species and distribution of black flies in the San-in district. Yonago Med. J., 9(4) : 566-579 (in Japanese).

Ono, H. (1976) : Redescription of the two black flies, Gnus daisensis TAKAHASI and Helodon multicaulis (POPOV) (Diptera, Simuliidae). Res. Bull. Obihiro Univ., 10 : 253-269.

Rubzow, I. A. (1959-1964): 14. Simuliidae (Melusinidae). In Lindner: Die Fliegen der Paläarktischen Region, Bd. III 4, 686 pp., Stuttgart.

Shiraki, T. (1935): Simuliidae of the Japanese empire. Mem. Fac. Sci. Agr. Taihoku Imp. Univ., $16: 1-90$.

Takahashi, H. (1950) : Fam. Simuliidae. Iconographia Insectorum Japonicorum. 1555-1559 pp., Hokuryukan, Tokyo (in Japanese).

\section{摘 要}

日本産ヤマブユ属 Genus Gnus (Diptera, Simuliidae) 1 新種の記載

著者は 1977 年 6 月下旬, 北海道渡島半島の調査にお いて檜山郡厚沢部町, 爾志郡熊石町および山越郡長万部 町の諸河川で多数のブニの老熟幼虫と蛹を採集した。こ れらを飼育して成虫を羽化させた結果，Gnus 属汇属す る新種であると認めたので，ここに Gnus fulvipes オ シマヤマブュ (新称) として記載する.

本種は Gnus 属 malyshevi 群の 4 種（ソ連の $m a$ lyshevi, lucidum, 日本・ソ連の albipes, 日本の daisense) に類似している. しかし，本種はこれらとは雌 雄の交尾器, 脚, 蛹, 蔽, 幼虫の額板の斑紋などの形質 の差により容易に区別できる.とくに本種の雄の交尾器 の腹面板は幅広いスペート型であり，陰葉には暗化した 長い鈎状棘と白色の短かい鈎状棘のほかに明瞭な橙色の 長い 2 本の棘状宛起があること, 生殖尾突起は顕著に幅 広くその先端が尖っていること, 蛹の呼吸系は 16 本の 呼吸系を有し基部は綎に細長く, 前方 2 対の呼吸系のみ 無柄できわめて太く膨隆していることなどは他の類似種 には見られない本種の特徴である。本種の茦は花かご型 であって，他の類似種のそれらよりも先端部がより緻密 に編まれている.

本種の老熟幼虫と蛹は 6 月下旬北海道渡島半島の川底 が石砂質のかなり急流の諸河川の小枝や枯葉などに多数 密着していることが観察された. 雌成虫の吸血性は不明 である。 